Sitasi artikel ini (APA 6 $^{\text {th }}$ Edition style):

Lubis, Herlina. (2019). Pemberian Penguatan Positif oleh Guru dalam Upaya Meningkatkan Motivasi Belajar Siswa pada Kompetensi Dasar Hubungan Satuan Panjang Pelajaran Matematika Kelas VB SD Negeri 067690 Medan Johor. MUKADIMAH, 2(2), 58-70.

\title{
PEMBERIAN PENGUATAN POSITIF OLEH GURU DALAM UPAYA MENINGKATKAN MOTIVASI BELAJAR SISWA PADA KOMPETENSI DASAR HUBUNGAN SATUAN PANJANG PELAJARAN MATEMATIKA KELAS VB SD NEGERI 067690 MEDAN JOHOR
}

\author{
Herlina Lubis, S.Pd \\ Guru SD Negeri 067690
}

\begin{abstract}
ABSTRAK
Adapun masalah pada penelitian ini adalah apakah pemberian penguatan positif seperti hadiah dapat meningkatkan motivasi berprestasi siswa kelas VB SD Negeri 067690 Medan Johor. Hipotesis yang diajukan dalam penelitian ini adalah: Motivasi berprestasi siswa akan meningkat jika diberikan penguatan positif berupa hadiah pada pembelajaran matematika di kelas VB SD Negeri 067690 Medan Johor. Populasi penelitian ini dilakukan terhadap seluruh peserta didik kelas II di SD Negeri 067257 Medan Amplas. Berjumlah 44 orang, dengan menggunakan penguatan positif (hadiah). Penelitian ini dilakukan untuk bidang studi Matematika Pokok Bahasan "Hubungan Satuan Panjang". Alat yang dilakukan untuk mengumpulkan data dalam penelitian ini adalah lembar observasi untuk guru, lembar observsi motivasi siswa dan daftar nilai siswa. Hasil penelitian menunjukkan bahwa pada kondisi awal, nilai rata-rata hitung siswa adalah 5,70 pada siklus I nilai rata-rata hitung siswa naik yaitu 6,02 sedangkan pada siklus II terjadi kenaikan yang sangat signifikan, nilai rata-rata siswa naik menjadi 8,81. Kesimpulan : Ada kolerasi antara penggunaan penguatan positif (hadiah) dengan motivasi berprestasi siswa.
\end{abstract}

Kata Kunci: Penguatan Positif, Motivasi Belajar, Pelajaran Matematika.

\section{PENDAHULUAN}

Hakikat matematika adalah pengetahuan tentang bilangan dan kalkulasi, matematika adalah pengetahuan tentang logika dan berhubungan dengan bilangan. Matematika dipelajari mempunyai tujuan bagi peserta didik yaitu mempersiapkan siswa agar dapat menggunakan matematika dan pola pikir matematika dalam kehidupan sehari-hari dalam mempelajari ilmu pengetahuan. 
Menghadapi hal masalah tersebut, perlulah guru melakukan sesuatu, dengan mengoptimalkan motivasi yang tinggi pada peserta didik, memberi semangat dan mengaktifkan siswa supaya tetap berminat dan siaga, mau memusatkan perhatian pada tugas-tugas matematika.

Adanya beberapa siswa yang mempunyai masalah dalam belajarnya seperti siswa malas belajar, acuh tak acuh, tidak bersemangat beraktivitas belajar matematika untuk memperbesar peranan peserta didik dalam aktivitas pengajaran perlu memberikan penguatan. Memberikan penguatan merupakan suatu keterampilan yang digunakan untuk memberikan umpan balik pada siswa bentuk kata-kata (verbal maupun non verbal). Tujuannya untuk meningkatkan motivasi belajar siswa dalam kegiatan belajar mengajar dan meningkatkan berulangnya kembali perbuatan positif atau aktif dalam belajar.

Siswa akan terdorong menyukai pelajaran matematika bila merasakan adanya kebutuhan terhadap pelajaran itu sehingga timbul usaha yang tinggi dalam belajar dan berprestasi. Siswa yang mendapat nilai bagus bila diberikan pujian akan merasa senang dan meningkatkan motivasinya dalam belajar serta jika ada siswa yang kurang rajin/malas belajar juga bisa diberi penguatan agar merasa terdorong dalam belajar misal dengan perkataan "coba, kamu pasti bisa" atau guru mengatakan sebagai penghargaan kepada siswa-siswanya "anak-anak siapa yang selesai secara cepat dan benar akan ibu beri buku tulis". Buku tulis dalam hal ini adalah bentuk penghargaan terhadap hasil karya siswa sebelum mereka bekerja. Tetapi pada saat terjadi aktivitas belajar yang real di sekolah adalah para guru kurang memperhatikan peserta didiknya di kelas, bahkan mereka sering mengabaikan pemberian penguatan atas pekerjaan, partisipasi dan ekspresi siswa dalam aktivitas belajar mengajar.

\section{METODE}

Jenis penelitian ini adalah Penelitian Tindakan Kelas (PTK). Dimana penelitian ini berupaya memaparkan pengaruh pemberian penguatan positif (hadiah) terhadap motivasi berprestasi siswa pada mata pelajaran matematika di kelas VB SD Negeri 067690 Medan Johor. Untuk mencegah terjadinya penafsiran yang berbeda serta untuk menciptakan kesamaan pengertian tentang variabelvariabel, maka penulis perlu merumuskan definisi operasional setiap variabel yang digunakan dalam penelitian ini yakni sebagai berikut:

- Variabel bebas (x): pemberian penguatan positif (reinforcement) adalah suatu penghargaan yang diberikan seorang guru sebagai penguat kepada terjadinya belajar yang sifatnya menggembirakan untuk memberikan respon sebagai tindak dorongan sehingga siswa senantiasa akan meningkatkan partisipasi aktifitas belajar lebih baik.

- Variabel terikat (y): motivasi berprestasi adalah suatu pendorong dan usaha sebagai kunci untuk memperoleh ukuran. Hasil belajar siswa sebagai penunjuk adanya prestasi tertentu yang dapat diukur. 
Desain penelitian yang dilaksanakan adalah desain yang menggunakan model Kemmis dan Mc. Taggart yang dikemukakan secara skematis seperti terlihat pada skema.

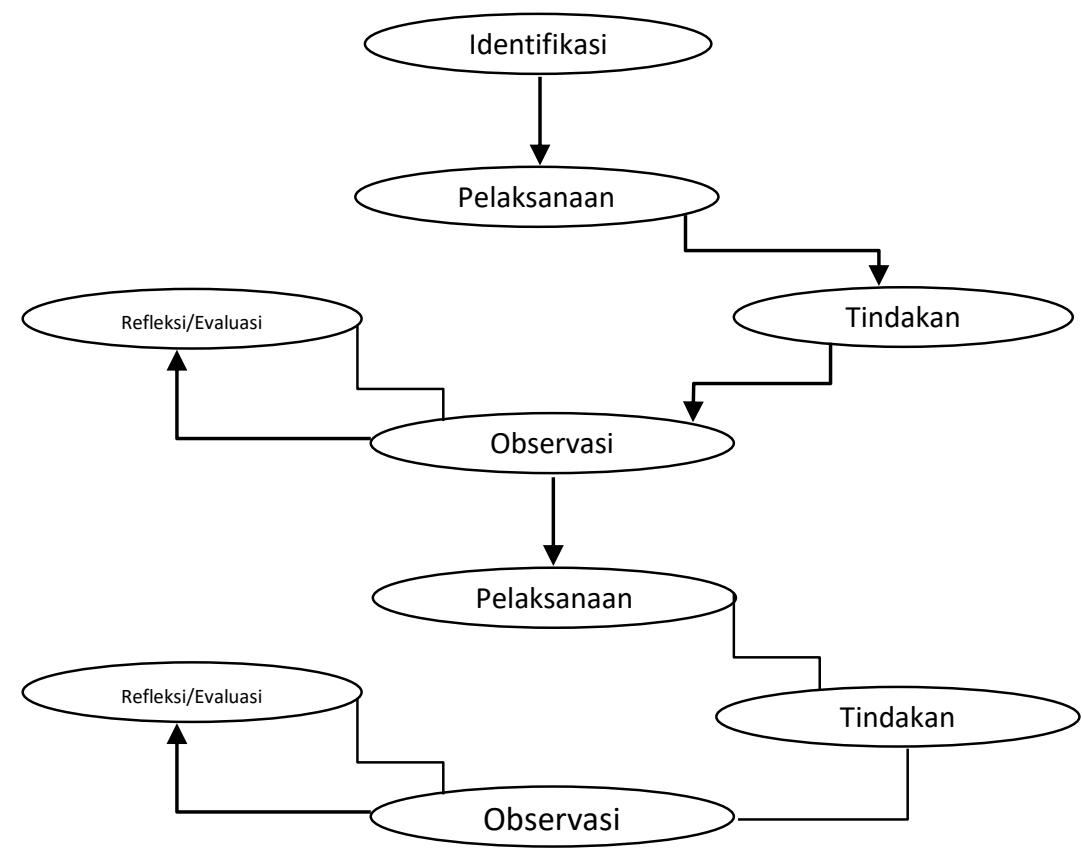

Gambar 1: Skema pelaksanaan tindakan kelas model Kemmis dan Mc. Taggart

Sesuai dengan jenis penelitian ini, yaitu penelitian tindakan kelas maka penelitian ini memiliki beberapa tahap pelaksanaan tindakan yakni dua siklus dimana setiap siklusnya mempunyai empat tahap yang akan dijelaskan sebagai berikut:

\section{Siklus I}

1) Perencaan

Kegiatan yang dilakukan dalam perencanan adalah :

a. Melakukan observasi awal untuk menemukan model dan format penerapan tindakan pada siklus I.

b. Menyusun rencana pembelajaran untuk setiap pertemuan yang memuat skenario pembelajaran dengan pemberian penguatan.

c. Guru memaparkan materi ajar, dan menjelaskan pengukuran satuan panjang.

d. Guru melakukan evaluasi setelah materi dijelaskan.

e. Menanggapi hasil kerja siswa dan memberikan penguatan agar siswa termotivasi untuk aktivitas belajar berikutnya. 
2) Pelaksanaan tindakan

Kegiatan yang dilaksanakan dalam tahap ini adalah melaksanakan tindakan sesuai dengan yang telah direncanakan, berupa proses pembelajaran sesuai dengan rencana pelaksanaan pembelajaran. Pelaksanaan berlangsung 2 kali pertemuan.

Tahap pelaksanaan tindakan sebagai berikut :

1. Peneliti memaparkan/melakukan penjelasan terhadap materi hubungan antar satuan panjang : secara jelas.

2. Memberikan kesempatan kepada siswa untuk memberikan respon tanya jawab tentang materi yang siswa kurang fahami.

3. Melakukan evaluasi berupa soal mengenai materi hubungan antar satuan panjang dan siswa mengerjakan.

4. Melakukan koreksi dan menilai tugas yang siswa selesaikan.

5. Mengadakan refleksi dimana siswa dapat memperbaiki jawaban yang salah agar nilai siswa lebih baik pada pertemuan berikutnya.

6. Memberikan penguatan positif berupa hadiah untuk siswa yang mendapat nilai bagus yakni mendapat nilai 9 dan 10 .

7. Memberi bimbingan kepada siswa kelas VI agar dapat meningkatkan nilai pada tugas yang diberikan pada pertemuan berikut.

\section{3) Observasi / Pengamatan}

Observasi yang dilaksanakan meliputi implementasi dalam monitoring pada proses pembelajaran matematika di kelas secara langsung. Kegiatan yang diamati meliputi aktifitas guru dan siswa dalam proses pembelajaran. Pengamatan ini bertujuan untuk mengetahui kesesuaian tindakan dengan rencana yang telah disusun dan guna mengetahui sejauh mana pelaksanaan tindakan dapat menghasilkan perubahan yang sesuai dengan hasil yang dikehendaki.

4) Refleksi

Kegiatan refleksi dilakukan untuk mempertimbangkan pedoman mengajar yang dilakukan serta melihat kesesuaian yang dicapai dengan yang diinginkan dalam pembelajaran matematika, untuk itu melakukan refleksi atas adanya kelemahan/ kekurangan tindakan yang telah dilakukan yang berguna memperbaiki pelaksanaan pada siklus berikut (Siklus II).

\section{Siklus II}

Pada siklus II akan dilaksanakan 4 (empat) tahapan yang akan dijelaskan sebagai berikut :

1) Perencanaan Tindakan II (Alternatif Pemecahan) 
Prosedur ini sama dengan siklus I dan pembelajaran dilakukan dengan memperbaiki kekurangan yang ditemukan pada siklus I. Dimana pada tahapan ini pelaksanaan diawali dengan proses belajar mengajar dengan kegiatan yang dilakukan dalam perencanaan masih sama yaitu :

a. Melakukan observasi awal untuk menemukan model dan format penerapan tindakan pada siklus II.

b. Menyusun rencana pembelajaran untuk setiap pertemuan yang memuat skenario pembelajaran dengan pemberian penguatan.

c. Guru memaparkan materi ajar, dan menjelaskan pengukuran satuan panjang.

d. Guru memberikan soal latihan setelah materi dijelaskan.

e. Menanggapi hasil kerja siswa dan memberikan penguatan agar siswa termotivasi untuk aktivitas belajar berikutnya.

1. Pelaksanaan Tindakan II

Penelitian melakukan kegiatan yang sama pada siklus I tetapi dilakukan setelah ada perbaikan.

Tahap pelaksanaan siklus II yaitu :

1. Peneliti menjelaskan materi mengenai hubunganantar satuan panjang kepada siswa kelas II.

2. Memberikan kesempatan bertanya bagi siswa yang kurang memahami materi.

3. Mengadakan evaluasi dengan memberi soal isian sebanyak 10 soal.

4. Melakukan penilaian tugas yang siswa selesaikan.

5. Melakukan refleksi dimana siswa dapat mengetahui jawaban mereka benar dan memperbaiki jawaban mereka yang salah.

6. Memberikan penguatan positif berupa hadiah kepada 3 orang mendapat nilai 10 dan 3 orang yang mendapat nilai 9.

\section{3) Observasi}

Pada waktu melakukan tindakan, peneliti melakukan observasi untuk mengetahui tingkat motivasi belajar siswa, perhatian siswa terhadap pembelajaran matematika, partisipasi dalam kegiatan pembelajaran dan keantusiasan terhadap materi yang diajarkan.

\section{4) Refleksi}

Kegiatan ini mencoba untuk melihat hasil perkembangan pelaksanaan dan memuat kesimpulan mengenai kekurangan atau kelebihan selama proses pemberian penguatan pada kegiatan belajar mengajar. Refleksi dilakukan untuk mengetahui ada tidaknya peningkatan motivasi belajar dari tindakan yang telah dilakukan. 
Untuk pengumpulan data dalam penelitian ini, teknik pengumpulan data yang akan digunakan berpedoman pada paradigma penelitian kualitatif. Ekowati dan Mulayani (2003:7) serta Soedarsono (2001:25) menyatakan penelitian bersifat kualitatif yaitu penelitian dimana data yang dikumpulkan dalam bentuk simbol seperti pernyataan-pernyataan dan perasaan. Sedangkan penelitian kuantitatif adalah penelitian yang datanya dilambangkan dengan simbol matematika yang berupa angka-angka. Alat pengumpulan data menurut Stringer (1999) dapat dilakukan melalui: (1) observasi, (2) wawancara, (3) dokumen, media dan peralatan, dan (4) rekaman informasi. Sedangkan alat yang digunakan antara lain: (1) pedoman pengamatan, (2) catatan lapangan dan annecdotal records, (3) analisis dokumen dan (4) perekam suara dan gambar (Ekowati dan Mulayani, 2003: 10).

Dalam penelitian tindakan ini, alat pengumpulan data yang digunakan penulis adalah:

\section{1) Observasi}

Dalam pengumpulan data selama proses pembelajaran berlangsung, dibantu juga oleh observer yaitu guru kelas VB di sekolah tersebut. Adapun perannya adalah mengamati aktifitas pembelajaran yang berpedoman pada lembar observasi yang telah disiapkan. Observasi dimaksudkan untuk mengetahui kesesuaian tindakan dengan rencana yang disusun dan untuk mengetahui sejauh mana pelaksanaan tindakan dapat menghasilkan perubahan yang sesuai dengan yang dikehendaki.

2) Tes

Tes awal diberikan untuk mengetahui tingkat pemahaman siswa terhadap pembelajaran matematika. Tes diberikan pada setiap siklus untuk memperoleh data tentang peningkatan motivasi belajar siswa.

\section{HASIL DAN PEMBAHASAN}

Langkah pertama yang dilakukan oleh guru adalah melakukan penjajakan atau identifikasi terhadap masalah yang akan diteliti dengan melakukan tes awal pada saat siswa berada di dalam kelas dengan menggunakan alat bantu Daftar Ceklist untuk melihat gejala motivasi berprestasi siswa yang ditandai dalam bentuk tingkat kreatifitasnya, kegigihan dalam mengerjakan tugas, produktifitas maupun inisiatif siswa dalam mengerjakan tugas, tingkat kecepatan siswa dalam menyelesaikan tugas, tingkat interaksi siswa dengan orang lain.

Kelas yang diobservasi dengan menggunakan daftar chek list adalah siswa kelas VB SD Negeri 067690 Medan Johor., dan berdasarkan hasil daftar chek list, hampir rata-rata siswa memiliki motivasi berprestasi yang rendah untuk tiap indikator yang telah ditetapkan. Di bawah ini merupakan hasil Daftar Check List pada saat observasi: 


\begin{tabular}{|l|l|c|c|c|}
\hline No. & \multicolumn{1}{|c|}{ Indikator } & $\begin{array}{c}\text { Kondisi } \\
\text { Awal }\end{array}$ & \% & Ket. \\
\hline 1. & $\begin{array}{l}\text { Puas terhadap nilai sebagai hasil usaha } \\
\text { sendiri. }\end{array}$ & 2 & 4,54 & Sangat Kurang \\
\hline 2. & Ciri-ciri prilaku belajar & & & \\
\hline & $*$ Kreatif & 10 & 22,72 & Kurang \\
\hline & $*$ Lebih gigih & 2 & 4,54 & Sangat Kurang \\
\hline & $*$ Energik & 4 & 9,09 & Sangat Kurang \\
\hline & $*$ Suka bertindak & 4 & 9,09 & Sangat Kurang \\
\hline & $*$ Produktif & 1 & 2,27 & Sangat Kurang \\
\hline & $*$ Penuh Inisiatif & 1 & 2,27 & Sangat Kurang \\
\hline & $\begin{array}{l}\text { Lebih tangguh dalam mengerjakan } \\
\text { suatu tugas }\end{array}$ & 2 & 4,54 & Sangat Kurang \\
\hline 3. & Menyukai tugas-tugas yang menantang & 9 & 20,45 & Kurang \\
\hline 4. & $\begin{array}{l}\text { Bertanggung jawab terhadap tugas } \\
\text { yang diberikan }\end{array}$ & 30 & 68,18 & Baik \\
\hline 5. & Suka berinteraksi dengan orang-orang & 10 & 22,72 & Kurang \\
\hline 6. & Selalu menyelesaikan tugas lebih cepat & 7 & 15,90 & Sangat Kurang \\
\hline 7. & Memiliki usaha yang sangat menonjol & 9 & 20,45 & Sangat Kurang \\
\hline 8. & Tidak suka membuang-buang waktu & 3 & 6,81 & Sangat Kurang \\
\hline 9. & Memiliki semangat yang tinggi & 2 & 4,54 & Sangat Kurang \\
\hline 10. & Tidak sepat putus asa & 5 & 11,36 & Sangat Kurang \\
\hline
\end{tabular}

Dari data hasil observasi di atas dapat diketahui bahwa motivasi belajar siswa kelas VB bisa dikatakan masih rendah, hal ini dapat dilihat dari:

1) Hanya ada 1 indikator untuk kriteria baik atau sebesar 5,54\% dari 18 indikator yang ada.

2) Ada 3 indikator untuk kriteria kurang atau sebesar 16,65\% dari 18 indikator yang ada.

3) Ada 14 indikator untuk kriteria sangat kurang atau sebesar 31,81\% dari 18 indikator yang ada.

Berdasarkan hasil di atas, maka peneliti berencana untuk melakukan penelitian tindakan kelas yang mengimplementasikan bimbingan belajar dengan melakukan perbaikan cara pengajaran.

Deskripsi Siklus I

\section{Perencanaan}

Kegiatan yang dilakukan dalam perencanaan adalah :

1. Melakukan observasi awal untuk menemukan model dan format penerapan tindakan pada siklus I.

2. Menyusun rencana pembelajaran untuk setiap pertemuan yang memuat skenario pembelajaran dengan pemberian penguatan.

3. Guru memaparkan materi ajar, dan menjelaskan pengukuran satuan panjang.

4. Guru melakukan evaluasi setelah materi dijelaskan. 
5. Menanggapi hasil kerja siswa dan memberikan penguatan agar siswa termotivasi untuk aktivitas belajar berikutnya.

Tindakan

Pada kegiatan ini, tindakan dilakukan peneliti bersama guru kelas dengan menerapkan metode penguatan positif berupa hadiah yang bertujuan untuk meningkatkan motivasi berprestasi siswa pada pelajaran matematika. Pada kegiatan ini peneliti menerapkan materi Hubungan Satuan Panjang.

Menyampaikan konsep Hubungan Satuan Panjang melalui metode penguatan positif yang bertujuan untuk meningkatkan motivasi berprestasi siswa. Dalam metode penguatan positif ini, siswa akan termotivasi, aktif sehingga akan berdampak pada hasil belajar siswa dan membantu siswa mengetahui apa yang harus dan apa yang tidak harus dilakukan dalam kegiatan pembelajaran.

Selain itu, peneliti juga menggunakan bahasa positif seperti "ya, bagus sekali", "baik sekali", "kamu memang anak pintar", "pendapat kamu tepat sekali", "wah cepat sekali kamu mengerjakannya". Pemberian bahasa positif ini diharapkan agar siswa merasa dihargai atas usaha dalam mengerjakan sesuatu dan pemberian bahasa positif ini diharapkan juga dapat memicu peningkatan hasil belajar siswa.

Kegiatan yang dilakukan untuk peningkatan motivasi berprestasi siswa dalam bentuk mandiri adalah sebagai berikut:

1) Memberikan contoh-contoh soal dan penyelesaiannya mengenai satuan panjang dalam pengukuran.

2) Meminta siswa untuk mengerjakan soal yang diberikan guru dan pembahasan dilakukan secara bergantian, siswa diminta maju ke depan kelas untuk mengerjakannya. Hal ini dimaksudkan untuk membuat siswa merasa puas terhadap nilai yang dicapainya dan sebagai penghargaan atas usahanya sendiri serta tanggung jawab terhadap tugas yang diberikan.

3) Memberikan penguatan positif dengan segera yakni berupa hadiahhadiah sederhana (alat-alat tulis) yang diberikan kepada siswa yang berani mengerjakan kedepan kelas dan yang memiliki nilai yang tinggi.

Kegiatan yang dilakukan untuk meningkatkan hasil belajar siswa dalam bentuk mandiri dengan cara memberikan tes berupa soal dikerjakan secara mandiri yang akan dinilai oleh pengajar.

Observasi

Pada tahap ini peneliti bersama guru kelas melakukan observasi dengan menggunakan alat bantu daftar chek list terhadap pelaksanaan kegiatan pembelajaran yang menggunakan metode pemberian penguatan positif.

Selama observasi banyak hal yang diperoleh antara lain: 
1) Siswa cepat berinteraksi dengan peneliti maupun berinteraksi dengan teman-teman sekelas dan teman-teman yang berlainan kelas dengan mereka.

2) Siswa selalu mengikuti kegiatan pembelajaran dengan penuh semangat tinggi dan tidak cepat putus asa dalam mengerjakan tugas yang diberikan oleh guru.

3) Pada kegiatan ini dapat dilihat bahwa banyak siswa yang memiliki tingkat kreatifitas, produktifitas, dan memiliki inisiatif yang cukup baik.

4) Pada kegiatan ini ada beberapa siswa masih enggan untuk mengemukakan pendapatnya.

5) Pada kegiatan ini masih ditemukan siswa yang lebih mementingkan bermain dari pada langsung mengerjakan tugas yang diberikan.

6) Pada penelitian ini ada banyak siswa yang lebih banyak bermain terlebih dahulu dari pada langsung mengerjakan tugas, sehingga mereka tidak dapat dengan cepat menyelesaikan pekerjaannya, selain itu pula ada beberapa siswa yang sama sekali tidak mengerjakan tugas yang diberikan oleh peneliti sehingga mereka tidak bertanggungjawab terhadap tugas yang diberikan.

Refleksi

Berdasarkan hasil observasi yang telah dilakukan pada siklus I maka peneliti melakukan refleksi terhadap seluruh kegiatan pada siklus I, yang hasilnya :

1) Pada awal kegiatan ini siswa memiliki respon yang sangat baik terhadap kehadiran peneliti yang akan meneliti kegiatan mereka serta guru yang akan memberikan beberapa materi pelajaran kepada mereka.

2) Pada siklus I masih ada siswa yang takut untuk mengemukakan pendapatnya di depan kelas.

3) Pada siklus I masih ditemukan siswa yang lebih mementingkan untuk bermain terlebih dahulu dari pada langsung mengerjakan tugas yang diberikan oleh peneliti.

Evaluasi

Pada kegiatan ini peneliti merefleksi dan mengevaluasi semua tahap kegiatan yang telah dilakukan mulai dari pelaksanaan kegiatan tindakan hingga observasi.

Tabel 2. Lembar Observasi Guru

\begin{tabular}{|c|c|c|c|c|c|}
\hline No & Indikator Siklus I & $\mathbf{A}$ & $\mathbf{B}$ & $\mathbf{C}$ & $\mathbf{D}$ \\
\hline \multirow[t]{3}{*}{1} & a) Menggunakan macam-macam penguatan positif & & & & \\
\hline & *Verbal & & & & $\checkmark$ \\
\hline & * Non Verbal (hadiah) & & & & \\
\hline 2. & b) Dapat memberikan penguatan positif dengan segera & & & $\checkmark$ & \\
\hline \multirow[t]{4}{*}{3.} & c) Memilih hadiah yang sederhana dan bermanfaat & & & & \\
\hline & * Bermanfaat untuk kelangsungan belajar siswa & & & $\checkmark$ & \\
\hline & * Diberikan secara sederhana dan tidak mahal & & & $\checkmark$ & \\
\hline & * Dapat menyajikan konsep matematika dengan baik & & & $\checkmark$ & \\
\hline
\end{tabular}


Dari tabel observasi guru menggunakan metode penguatan positif berupa hadiah pada siklus I di atas, dapat dilihat:

1) Ada 2 indikator guru yang memperoleh nilai $D$ dari 6 indikator yang ada, yaitu pada indikator menggunakan macam-macam penguatan positif verbal dan menggunakan macam-macam penguatan positif non verbal.

2) Ada 4 indikator yang memperoleh nilai $C$ dari 6 indikator yang ada, yaitu dapat memberikan penguatan positif dengan segera, memilih hadiah yang sederhana dan bermanfaat untuk kelangsungan belajar siswa, diberikan secara sederhana dan tidak mahal, dan dapat menyajikan konsep matematika dengan baik.

Dari lembar observasi guru pada tabel 4, dapt ditarik kesimpulan bahwa guru kurang memfungsikan metode pemberian penguatan positif.

Deskripsi Siklus II

Tindakan

Pada kegiatan ini, tindakan dilakukan peneliti bersama guru kelas dengan menerapkan metode penguatan positif berupa hadiah yang bertujuan untuk meningkatkan motivasi berprestasi siswa pada pelajaran matematika. Pada kegiatan ini peneliti menerapkan materi Hubungan Satuan Panjang.

Menyampaikan konsep Hubungan Satuan Panjang melalui metode penguatan positif yang bertujuan untuk meningkatkan motivasi berprestasi siswa. Dalam metode penguatan positif ini, siswa akan termotivasi, aktif sehingga akan berdampak pada hasil belajar siswa dan membantu siswa mengetahui apa yang harus dan apa yang tidak harus dilakukan dalam kegiatan pembelajaran.

Kegiatan yang dilakukan untuk peningkatan motivasi berprestasi siswa dalam bentuk mandiri adalah sebagai berikut:

1) Memberikan contoh-contoh soal dan penyelesaiannya mengenai satuan panjang dalam pengukuran.

2) Meminta siswa untuk mengerjakan soal yang diberikan guru dan pembahasan dilakukan secara bergantian, siswa diminta maju kedepan kelas untuk mengerjakannya. Hal ini dimaksudkan untuk membuat siswa merasa puas terhadap nilai yang dicapainya dan sebagai penghargaan atas usahanya sendiri serta tanggung jawab terhadap tugas yang diberikan.

3) Memberikan penguatan positif dengan segera yakni berupa hadiahhadiah sederhana (alat-alat tulis) yang diberikan kepada siswa yang berani mengerjakan ke depan kelas dan yang memiliki nilai yang tinggi.

Kegiatan yang dilakukan untuk meningkatkan hasil belajar siswa dalam bentuk mandiri dengan cara memberikan tes berupa soal dikerjakan secara mandiri yang akan dinilai oleh pengajar. 


\section{Observasi}

Pada tahap ini peneliti bersama guru kelas melakukan observasi dengan menggunakan alat bantu daftar chek list terhadap pelaksanaan kegiatan pembelajaran yang memberikan penguatan positif yang berupa hadiah-hadiah sederhana. Berdasarkan hasil observasi yang telah dilakukan oleh peneliti bersama dengan guru kelas diperoleh hasil bahwa 9 indikator atau sekitar $50,00 \%$ kriteria sangat kurang.

Refleksi

Berdasarkan hasil refleksi yang telah dilakukan, maka diperoleh hasil bahwa:

1) Pada siklus II banyak siswa yang sudah berani tampil dan mengajukan pendapat mereka tanpa diminta oleh peneliti terlebih dahulu.

2) Semua siswa sudah mengalami kemajuan bila dilihat dari indikatorindikator yang sudah ditentukan peneliti.

Evaluasi

Pada kegiatan ini peneliti merefleksi dan mengevaluasi semua tahap kegiatan yang telah dilakukan mulai dari pelaksanaan kegiatan tindakan hingga observasi.

Tabel 3.

Lembar Observasi Guru Siklus II

\begin{tabular}{|l|l|c|c|c|c|}
\hline No & \multicolumn{1}{|c|}{ Indikator Siklus II } & A & B & C & D \\
\hline 1 & a) Menggunakan macam-macam penguatan positif & & & & \\
\hline & $*$ Verbal & $\checkmark$ & & & \\
\hline & $*$ Non Verbal (hadiah) & $\checkmark$ & & & \\
\hline 2. & b) Dapat memberikan penguatan positif dengan segera & $\checkmark$ & & & \\
\hline 3. & c) Memilih hadiah yang sederhana dan bermanfaat & & & & \\
\hline & * Bermanfaat untuk kelangsungan belajar siswa & $\checkmark$ & & & \\
\hline & $*$ Diberikan secara sederhana dan tidak mahal & & $\checkmark$ & & \\
\hline & * Dapat menyajikan konsep matematika dengan baik & $\checkmark$ & & & \\
\hline
\end{tabular}

Dari tabel observasi guru menggunakan alat peraga pada siklus II di atas, dapat dilihat :

1. Ada 5 indikator guru yang memperoleh nilai A dari 6 indikator yang ada, yaitu pada indikator menggunakan macam-macam penguatan positif yang bersifat verbal, yang bersifat non verbal, dapat memberikan penguatan positif dengan segera, memilih hadiah yang bermanfaat untuk kelangsungan belajar siswa dan dapat menyajikan konsep matematika dengan baik.

2. Hanya ada 1 indikator yang memperoleh nilai B dari 6 indikator yang ada, yaitu diberikan secara sederhana dan tidak mahal.

Dari lembar observasi guru dapat disimpulkan bahwa guru sudah mulai dapat memfungsikan penguatan positif dengan baik. 


\section{Refleksi}

Berdasarkan hasil evaluasi pada siklus I dan siklus II yang telah dilakukan oleh peneliti, maka terjadi perubahan yang terlihat selama penelitian yang dapat dengan mudah dilihat pada tabel 7 dibawah ini.

Tabel 4. Lembar Keseluruhan Observasi Guru

\begin{tabular}{|c|c|c|c|c|c|c|c|c|c|}
\hline \multirow[t]{2}{*}{ No } & \multirow[t]{2}{*}{ Indikator Siklus } & \multicolumn{4}{|c|}{ Siklus I } & \multicolumn{4}{|c|}{ Siklus II } \\
\hline & & $\mathbf{A}$ & B & $\mathbf{C}$ & D & $\mathbf{A}$ & B & $\mathbf{C}$ & D \\
\hline 1 & Menggunakan macam-macam penguatan positif & & & & & & & & \\
\hline & $*$ Verbal & & & & $\checkmark$ & $\checkmark$ & & & \\
\hline & * Non Verbal (hadiah) & & & & $\checkmark$ & $\checkmark$ & & & \\
\hline 2. & Dapat memberikan penguatan positif dengan segera & & & $\checkmark$ & & $\checkmark$ & & & \\
\hline 3. & Memilih hadiah yang sederhana dan bermanfaat & & & & & & & & \\
\hline & * $\quad$ Bermanfaat untuk kelangsungan belajar siswa & & & $\checkmark$ & & $\checkmark$ & & & \\
\hline & * $\quad$ Diberikan secara sederhana dan tidak mahal & & & $\checkmark$ & & & $\checkmark$ & & \\
\hline & $\begin{array}{l}\text { * Dapat menyajikan konsep matematika dengan } \\
\text { baik }\end{array}$ & & & $\checkmark$ & & $\checkmark$ & & & \\
\hline
\end{tabular}

Dari tabel di atas, dapat dilihat bahwa guru sudah meningkatkan penggunaan penguatan positif dengan baik. Dari hari observasi di atas dapat dilihat bahwa semua indikator yang ada telah mengalami peningkatan yang cukup signifikan. Dari 18 indikator ada 5 indikator yang sangat mengalami peningkatan hingga mencapai kriteria sangat baik yaitu indikator Energik, Suka bertindak, Menyukai tugas-tugas yang menantang, Suka berinteraksi dengan orang-orang dan ada indikator Suka berinteraksi dengan orang-orang. Pada indikator energik peningkatan ini dapat terjadi dikarenakan peneliti selalu memberikan penguatan yang berupa hadiah dan siswa selalu energik untuk mengeluarkan semua ide-idenya tanpa memberikan batasan, seperti memberikan alat-alat tulis.

Peningkatan juga terjadi pada indikator suka bertindak ini dikarenakan peneliti menghargai tindakan yang dilakukan oleh siswa tanpa menyinggung perasaan atau mempermalukan siswa tersebut.

Peningkatan juga terjadi pada indikator Suka bertindak, ini dikarenakan peneliti selalu memberikan pujian kepada siswa yang lebih cepat menyelesaikan tugas seperti memberi nilai dan mengucapkan "bagus sekali", "baik sekali", "kamu pintar" dan lain-lain.

Faktor penghambat pada penelitian ini adalah masih belum siapnya siswa menghadapi situasi pembelajaran yang baru diterapkan oleh peneliti baik itu dalam hal mengemukakan ide, selalu maju ke depan kelas dalam mengerjakan tugas, mendengarkan instruksi yang diberikan oleh peneliti dan kurang siapnya peneliti dalam menghadapi situasi yang baru.

Faktor pendukung selama penelitian ini berlangsung adalah siswa memiliki kemauan yang kaut dalam mengikuti kegiatan pembelajaran dan beradaptasi dengan peneliti dan banyak siswa yang senang dalam mengikuti pembelajaran. 
Dapat dilihat bahwa banyak nilai siswa mengalami peningkatan sehingga 44 siswa sudah mencapai ketuntasan dan hanya 2 siswa yang belum mencapai ketuntasan. Dari hasil temuan yang dibuat oleh peneliti maka dapat disimpulkan hipotesis yang diajukan peneliti yaitu "Motivasi berprestasi siswa akan meningkat jika diberikan penguatan positif berupa hadiah pada pembelajaran matematika di kelas VB SD Negeri 067690 Medan Johor.

\section{KESIMPULAN}

Berdasarkan hasil dan pembahasan penelitian tindakan kelas yang dilakukan dengan pemberian penguatan positif pada pembelajaran matematika di Kelas VB SD Negeri 067690 Medan Johor.

1. Kesimpulan Hasil

Pemberian penguatan positif (hadiah) berupa alat-alat tulis pada proses pembelajaran matematika dapat meningkatkan motivasi untuk prestasi belajar siswa.

2. Kesimpulan Proses

Pemberian penguatan positif pada pembelajaran matematika dapat meningkatkan keaktifan siswa, keantusiasan mengikuti pembelajaran matematika serta dapat meningkatkan angka-angka prestasinya.

\section{Saran}

Saran yang dapat disampaikan dari hasil penelitian ini adalah:

1. Kepada guru mata pelajaran matematika diharapkan dapat menerapkan pemberian penguatan positif yang berupa hadiah, alat-alat tulis yang bermanfaat pada saat pembelajaran metematika berlangsung. Melalui hal tersebut siswa memiliki semangat yang tinggi karena guru mampu memotivasi untuk mencapai prestasi yang lebih baik.

2. Kepada siswa agar mampu aktif saat pembelajaran matematika serta berpacu untuk mendapatkan prestasi yang lebih baik.

\section{REFERENSI}

Djamarah, S.B. (2000). Guru dan Anak Didik Dalam Interaksi Edukatif. Jakarta: Rineka Cipta.

Hamalik, Oemar (2007). Kurikulum dan Pembelajaran. Bandung: Bumi Aksara.

Jatmiko, 2003. Penelitian Tindakan Kelas. Jakarta: Departemen Pendidikan dan Kebudayaan.

Purwanto, Ngalim. (2006). Psikologi Pendidikan. Bandung: PT. Remaja Rosdakarya.

Sardiman A.M, (2006). Interaksi Motivasi Belajar. Jakarta: Raja Grafindo Persada. 